\title{
KULTURA AUTOBIOGRAFICZNA
}

\section{Making Love and Make-Belief: Male Sexual Barter in Dov Freiberg's To Survive Sobibor}

\section{Summary}

After escaping the German mass killing facility in Sobibór on 14 October 1943, Dov Freiberg and Semyon Rozenfeld survived in hiding near Chelm until the arrival of the Red Army in July 1944. In 1945, Freiberg testified before the Central Jewish Historical Commission, and in 1988, he published his much more extensive memoirs To Survive Sobibor. Both texts cover the period of hiding, during which Freiberg, Rozenfeld and the brothers Dawid and Józef Serczuk were taken in by two women. The two sources reveal an episode of male sexual barter, as the male group established rational relationships with the two women in order to stabilize a precarious situation. By comparing both of Freiberg's texts, it becomes clear that so-called late testimonies are rich and unjustly underrated source-material.

\section{Keywords}

Sobibór, Dov Freiberg, Semyon Rozenfeld, Dawid Serczuk, Józef Serczuk, sexuality and the Holocaust, Jews in hiding

\footnotetext{
* Contact with the author: raphael.utz@uni-jena.de.
} 
Published in English translation in 2007, Dov Freiberg's 1988 memoirs have remained a much-overlooked contribution to the autobiographical literature on the German mass killing facility in Sobibór. ${ }^{1}$ This is all the more regrettable as half of the 600-page volume tells the story of Freiberg's life after his escape from Sobibór in the course of the uprising on 14 October 1943. Therefore, we learn about a period, which is usually not the focus of survivor writings - the time between the escape and the arrival of the Red Army in July 1944. Given the hostile and dangerous environment they found themselves in, it is no coincidence that of the approximately 275 forced labourers who managed to leave the perimeters of Sobibór, only approximately 57 were still alive eight months later. ${ }^{2}$ Freiberg is no exception when he tells us about adverse weather conditions, the German efforts at capturing and killing the Sobibór escapees, the mortal danger from Polish partisan groups, and the ambivalent and often outright hostile attitude of the local population. What is truly remarkable, however, is the central episode of his chapter "The Forests" covering those eight months. ${ }^{3}$ However, the key period of the winter 1943/1944 did not take place in a forest at all. And at its heart is a story of male sexual barter in order to ensure survival. A close reading of this story in Freiberg's book will be the focus of this article.

Until recently, accounts written many decades after the events they present and intended for publication have been viewed with some distrust by historians. Christopher Browning and Anna Hájková are among those who have challenged this notion and who have argued for studying ego-documents from all periods available. Later testimonies or books can relate information the author was uncomfortable to reveal in earlier contexts and situations. ${ }^{4}$

To delineate such narrative shifts, Freiberg's 1945 testimony to the Jewish Historical Commission in Łódź will be consulted extensively as well. It is important to remember, however, that this earlier deposition was much shorter and served a very different purpose. Moreover, it was put into writing by Bluma Wasser, a member of the Commission, and it remains unclear to what extend she edited Freiberg's statement. ${ }^{5}$

1 Dov Freiberg, To Survive Sobibor (Jerusalem-New York: Gefen, 2007).

2 Marek Bem, Sobibor Extermination Camp 1942-1943, transl. Tomasz Karpiński, Natalia Sarzyńska-Wójtowicz (Amsterdam: Stichting Sobibor, 2015), 299-300.

3 Freiberg, To Survive, 299-393.

4 Christopher R. Browning, Remembering Survival: Inside a Nazi Slave-Labor Camp (New York: Norton, 2010); Anna Hájková, "Strukturen weiblichen Verhaltens in Theresienstadt," in: Genozid und Geschlecht: Jüdische Frauen im nationalsozialistischen Lagersystem, ed. Gisela Bock (Frankfurt a. M.: Campus, 2005), 202-219.

5 Berek Freiberg, “Sobibór,” in: Nach dem Untergang. Die ersten Zeugnisse der Shoah in Polen 1944-1947. Berichte der Zentralen Jüdischen Historischen Kommission, eds. Frank Beer, Wolfgang Benz, Barbara Distel (Dachau-Berlin: Verlag Dachauer Hefte-Metropol, 2014), 617-652. 
Sexuality remains an uncomfortable subject in the context of the Shoah. Usually, it is discussed as sexual violence directed against women. ${ }^{6}$ The case Dov Freiberg relates in his memoirs is a different one - it is men who offer sexual acts as currency in the economy of securing survival. What this article explores, therefore, is one particular case of a "rational relationship,” defined by Anna Hájková as “any instance or combination of social, sexual, and romantic relationships in which one or both of the partners engaged for at least partly pragmatic reasons." 7

\section{The Men}

Dov Freiberg was born as Berek Freiberg in Warsaw on 15 May 1927, and he arrived at Sobibór on his 15th birthday in 1942. ${ }^{8}$ Selected for forced labour, he survived until the uprising 18 months later, in which he took an active part. Initially, Freiberg found himself in a group of 24 who had fled "in the same direction." 9 After three days, they were tricked by a group of Polish partisans who opened fire on them. After a narrow escape, Freiberg found himself alone with two other men: "Abraham Rajz from Tyszowce" and "Szymon Rozenfeld from the Minsk transport” - Semyon Moiseevich Rozenfeld. ${ }^{10}$ Rajz is only mentioned by name in Freiberg's 1945 testimony, and in his memoirs, he remembers him as "eighteen years old, two years my elder, a boy with the face of a doll - round head, cheeks full and always red. He was short and chubby, but still half a head taller than I was."11

Rozenfeld was born on 10 October 1922 in Ternivka, Ukraine. From Minsk, he was deported to Sobibór on 22 September 1943 as part of a group of Soviet prisoners of war, together with Aleksandr (Sasha) Pechersky, the military leader of the uprising on 14 October $1943 .^{12}$ Freiberg describes Rozenfeld as “large, tall and twice as wide as I was.” He continues:

6 For example, Zoë Waxman, Women in the Holocaust: A Feminist History (Oxford: Oxford University Press, 2017).

7 Anna Hájková, “Sexual Barter in Times of Genocide: Negotiating the Sexual Economy of the Theresienstadt Ghetto,” Signs 38 (2013), 3: 503-533, here 512.

8 Bem (Sobibor, 364) lists the deportation from Turobin to Sobibór as having taken place on 12.05.1942. Freiberg explains in his 1945 testimony, that the journey took "two days and two nights" (see Freiberg, "Sobibór”, 620).

9 Freiberg, “Sobibór”, 641.

10 Ibidem, 643.

11 Freiberg, To Survive, 305. Rajz is not mentioned in any list of known survivors the author is aware of.

12 See: Semjon Rosenfeld, Wikipedia, access 30.08.2020, https://de.wikipedia.org/wiki/Semjon_Rosenfeld. Surprisingly, the English version is much shorter and gives a different place of birth. 
He moved heavily, like a bear, and I thought he personified the typical Russian soldier. He was cynical and acted as though nothing in the world was important to him. During the revolt, he had killed one of the Germans, but it had been difficult for him to run during the flight, and he had taken off his long overcoat and another shorter coat, and was now wearing only a shirt. ${ }^{13}$

The three young men took stock of the situation: "We decided to go to Tyszowce, because Rajz knew peasants there, and so we got on our way." ${ }^{14}$ As neither Freiberg who had spent most of his life in Łódź nor Rozenfeld knew the area, they followed the only member of the group with local knowledge and potential contacts. The task, however, was not an easy one, as Tyszowce is more than $100 \mathrm{~km}$ to the south of Sobibór. It is impossible to reconstruct the group's location at the time of the decision to head south. However, it is that they first tried to reach the forest around the village of Sawin, because they had heard that partisans operated there. After this proved unsuccessful, they moved on towards Chełm. Probably somewhere near the town Rejowiec, $10 \mathrm{~km}$ west of Chełm, they met a Jewish group hiding in the forest. ${ }^{15}$ Freiberg relates the shock of the first encounter:

As if he had sprung up from the underground, a man appeared in front of us. He was short, had an axe in his hand, and shouted at us in Polish, "Hands up!” The man's face was pale and serious, the axe in his hand was lifted toward us, but suddenly he said in Yiddish, "Are you Jews?" "Yes," we all answered at the same time. His pale face broke into a smile, and he said, "Don’t be afraid. You are among Jews!"16

They had come across Dawid Serczuk. ${ }^{17}$ And a moment later, his brother Józef Serczuk enters Freiberg's narrative:

At the same time, another man appeared who did not look Jewish at all - his hair was blond and straight, his eyes were blue, and his broad shoulders and clothing marked him as a farmer. He walked toward us and welcomed us in Yiddish, shalom aleichem, welcome, Jews. ${ }^{18}$

\footnotetext{
13 Freiberg, To Survive, 305.

14 Idem, "Sobibór”, 643.

15 Ibidem.

16 Idem, To Survive, 318.

17 Idem, "Sobibór”, 643.

18 Idem, To Survive, 318.
} 
The Serczuk brothers are listed as survivors of Sobibór, and Thomas Blatt mentions them as having escaped from Sobibór in the course of the uprising. ${ }^{19}$ The available information states that Józef was born in 1919 in Chełm, which would have made him 24 at the time. ${ }^{20}$ In Freiberg's two narratives, however, their stories are quite different. Józef Serczuk is quoted as saying: "We want to survive. We have been here for ten months now, and we want to continue surviving." ${ }^{21}$ In his memoirs, Freiberg states that Dawid (whom he calls Monyek) was the elder of the two brothers and had received a good education staying with relatives in Warsaw. Returning home to Chełm at the beginning of the war, he tried to convince his parents to seek refuge in the Soviet Union. His parents, however, objected on religious grounds, and Dawid left alone - only to come back to Chełm one year later, disillusioned with the Soviet style of government. Here, the family had continued to run their business, a shop selling chickens. ${ }^{22}$ Freiberg writes about Józef, whom he calls Józik or Yozhik:

Yozhik, his younger brother, had helped his father in the shop from the time that he was a child and would travel with him to villages to buy chickens. When he got older, he would go to the neighbouring villages alone, which was how he learned about the farmers' way of life and became friendly with them. He had sometimes had to return home during the night, and so had learned to defend himself against attackers, both human and animal. When the Germans entered Chelm, and life became harder and harder for the Jews, Yozhik became the only breadwinner of the family, as his non-Jewish appearance allowed him to continue going to surrounding villages to buy chickens. ${ }^{23}$

After the first deportation from the Chełm ghetto to Sobibór on 21 May 1942, which the Serczuk family had managed to escape, Józef removed his family to a village, where they hid with a local peasant. ${ }^{24}$ The two brothers would work the fields as part of the agreement. After one such day and upon their return, they discovered that their family had been taken

19 See: List of survivors of Sobibor, Wikipedia, access 13.08.2020, https://en.wikipedia.org/wiki/List_of_survivors of_Sobibor; Thomas Toivi Blatt, Sobibór - der vergessene Aufstand (Hamburg-Münster, UNRAST Verlag, 2004), 149.

${ }^{20}$ See: Joseph Serchuk, Wikipedia, access 13.08.2020, https://en.wikipedia.org/wiki/Joseph_Serchuk.

${ }^{21}$ Freiberg, "Sobibór”, 643.

22 Freiberg, To Survive, 319-320.

23 Ibidem.

${ }^{24}$ For deportations from Chełm to Sobibór, see: Yitzhak Arad, Belzec, Sobibor, Treblinka: The Operation Reinhard Death Camps (Bloomington-Indianapolis: Indiana University Press, 1987), 390; Marek Bem, Sobibor, 364. 
by the Germans. ${ }^{25}$ The two brothers then fled to the forest, where they hid for many months and gathered ten others around them. A first group of five men from Sobibór must have reached them only a few days before Freiberg, Rozenfeld and Rajz did at the end of October 1943. ${ }^{26}$ Neither in his 1945 testimony nor in his 1988 autobiography does Freiberg describe the Serczuk brothers as survivors of Sobibór. Had they both ever been there and made their escape, Freiberg would have mentioned it.

In the forest, the 15 men built and inhabited different dugouts. ${ }^{27}$ During the day, some of them would engage with what Freiberg called "work” in 1945. Joined by four armed cousins of the Serczuk brothers, it appears that the group engaged in purchases, mainly of food, making use of Józef Serchuk's knowledge about poultry farmers and their livestock in the area. ${ }^{28}$ The economic basis for this trade, at least in part, were the valuables brought along by the Sobibór escapees. ${ }^{29}$ In his autobiography, Freiberg writes:

At night, Yozhik would buy food from farmers for the whole group. The people from Sobibór had money, and Chaim, the jeweller, had taken a large amount of gold. Yozhik would usually go alone, but occasionally Monyek [Dawid Serczuk] would go with him; very infrequently, they would take someone from the group to help them carry sacks of food from the villages. Yozhik said that people who were not used to the forest would become frightened at every hopping bird and every passing squirrel, and that the Sobibór people didn't know how to behave in the villages, and so it was better for him to go out to get food alone. ${ }^{30}$

Józef Serchuk is the central character in Freiberg's two narratives. Freiberg's admiration for him is evident in his 1988 memoirs:

Yozhik had good connections in all of the villages. He knew every farmer and he knew who was trustworthy. He also had contacts with Jews who were hiding with farmers, including his uncle, aunt, and their child, and another uncle who had been alone since the Germans had killed his family. Yozhik looked after them, visiting them from time to time and making sure that they were all right. He also said that there were three Czech Jews in hiding, who had had professions that were useful to the Germans; the Germans

\footnotetext{
25 Freiberg, To Survive, 320.

26 Idem, “Sobibór”, 643; idem, To Survive, 318-319.

27 Idem, “Sobibór”, 643.

28 Ibidem, 643-644.

29 Ibidem, 644; Freiberg, To Survive, 301.

30 Freiberg, To Survive, 324.
} 
had kept them working in one of the camps until the Gestapo had demanded them. They had found out in time that they were to be taken and had run away, and for the past half year they had been hiding with a farmer. This farmer told Yozhik that he wanted to go on giving them shelter, but that his wife, who feared the Germans, gave him no peace, and they would have to leave. The Czechs told Yozhik that the real reason the farmer wouldn't harbour them any longer was that their money had run out, so Yozhik had asked the farmer to keep them there for a few more days and gave him money to buy food for them. Now that the bunker was ready, he intended to bring them to the forest. ${ }^{31}$

In 1945, Freiberg described him as "In one word, Józek was our commander. We set up our own group of partisans." 32

However, this life ended in the course of November 1943. The dugouts were discovered by Poles, and after a series of raids and killings, the Serczuk brothers, Rajz, Rozenfeld, four other men and Freiberg had to leave, being the sole survivors. ${ }^{33}$ The group separated further, and in the end, Freiberg stayed with Rozenfeld and the Serczuk brothers. ${ }^{34}$ For a few days, they found shelter with a peasant named Karpiuk, and from there, they moved on to an isolated house at the edge of a settlement (kolonia) of another village. This house had belonged to an uncle of the Serczuks, and the group presumed that it would be empty. Karpiuk promised that he would continue to provide food as the house was only $5 \mathrm{~km}$ away. When the four young men reached the place, however, they found that it was occupied - by two women and a small child.

\section{The Women}

The women who had taken over the empty Jewish house lived on the periphery of the village and of village society. Yanka and Yula were, in fact, outcasts as became clear to the four young men very quickly: ${ }^{35}$

\footnotetext{
31 Ibidem, 327.

32 Freiberg, "Sobibór", 644.

33 See the two versions in: ibidem, 644-646; Freiberg, To Survive, 329-341.

34 Freiberg, To Survive, 340; idem, “Sobibór”, 646.

35 It remains unclear whether the two women were sisters. See Freiberg ("Sobibór”, 649), where the man is described as "the brother of the women." In his 1988 memoirs, Freiberg speaks of the man as Yula's brother (see: idem, To Survive, 351).
} 
Yanka was in her twenties, tall and well formed, and her size made her look older than she really was. To me, she symbolized the strength of women. She had wide shoulders, and her arms and legs were heavy. Her head was round and her nose wide and upturned, and her grey eyes were always watery, as though she were about to cry. Her voice was deep and quiet. She was shy and spoke little. Yula was short and very thin, flat-chested, her face wrinkled, her nose small and sharp, her eyes blinking and always a bit closed, her hair black and uncombed and her voice hoarse and shrill. She talked quite a bit, and when she spoke, the veins in her temples and neck stood out. She was nervous and angered easily. She was raising her child on her own - Kazia, about a year old, was the daughter of a German soldier who had been passing through. ${ }^{36}$

In addition, Yanka was already pregnant by a Volksdeutscher. ${ }^{37}$ They were, in Freiberg's words, "not the most respectable of women." 38 Yanka did stay in touch with her mother, though, who lived in a village $10 \mathrm{~km}$ away. ${ }^{39}$ Neither Yanka, nor Yula is described as particularly intelligent, but Yula in particular comes across as "wicked and anti-Semitic [sic!]” and uneducated. ${ }^{40}$ Both women lived in dire economic circumstances. Their poverty and the fact that they were (or soon would be) single mothers by men from among the enemy in the eyes of the local community, was not the only reason making them outcasts, however. The four men soon found out that Stashek, Yula's brother, was part of a local gang of thieves and robbers with three more members - Vladek, Bronek and "Pan Folka." ${ }_{11}$

\section{The Barter}

The arrangement between the four young men and the two women consisted of two elements, which were established within two days. For offering shelter with them, the women were to benefit economically, and the men were to join Stashek and his gang in their robberies. In order to stabilise this precarious and fragile constellation, strategically the Jewish men made love and sex part of the equation. In his 1945 testimony, Freiberg describes this strategy as follows:

\footnotetext{
36 Idem, To Survive, 349-350.

37 Ibidem, 367; Freiberg, “Sobibór”, 648.

38 Freiberg, To Survive, 354.

39 Ibidem, 379.

40 Ibidem, 366.

${ }^{41}$ Freiberg, "Sobibór”, 647; idem, To Survive, 351-352.
} 
We did everything to save our lives. We did a whole lot of other things to save our lives. We sold ourselves completely. We told the women that we would marry them after the war and live in the city. They would be written about in the papers, and we would give them money and diamonds, they would be the envy of the village. The child to be born would be driven around in a pram the likes of which the world had never seen, and abroad it would be known what important Jews they had saved. We worked hard and played the part. We put a lot of effort into it. ${ }^{42}$

What this meant, Freiberg spelt out further 40 years later, recalling their arrival at the house and Józef Serczuk's attempts to convince the women to open their door:

The door opened and Yozhik was swallowed up inside. He was in there for a long time. At last, when we had lost patience, he appeared, with a smile on his face. "We have found an excellent place to stay," he announced. "Two women and a small child are living in the house. They are very poor and they have nothing to eat. I promised them that, if I stayed with them, they would eat like queens, and that from now on, they would lack for nothing. They are willing to do anything. I have already slept with one of them, and she was fine.”3

In Freiberg's two narratives, three central elements of this strategy are related in great detail: first, delivering economic benefits leading to a significant improvement in the women's situation; second, the affirmation of the women's prejudices and social milieu in order to minimise differences and conflict; and third, active role-play taken on by the men to inject their claims of emotional involvement with credibility.

Józef Serczuk managed to improve the material situation of Yula and Yanka. It remains unclear, however, by which means. Presumably, the remaining gold coins Freiberg had taken out of Sobibór helped in keeping them afloat. A key figure in this was the farmer Karpiuk with whom they met regularly and at whose house they enjoyed large meals paid for by the four men. ${ }^{44}$ Through him, they acquired the provisions they now needed. ${ }^{45}$ The relationship with Karpiuk served an additional purpose - to demonstrate that the four men were not dependent on the two women, that they had alternatives. This was all the more important

\footnotetext{
42 Idem, “Sobibór”, 647-648.

43 Idem, To Survive, 348.

44 Ibidem, 366-367.

45 Ibidem, 349.
} 
as the power dynamic shifted with the successful improvement of living conditions. In Freiberg's recollection:

Yozhik analyzed the situation thus: We had found two women who had nothing to live on, and now they were satisfied, as we were taking care of all their needs; but in a while, they would be sated and they would begin to feel the danger of our presence. Then they would either make us leave or they would inform on us. ${ }^{46}$

The fact that the four young men joined the local gang of criminals certainly served economic purposes - they came into possession of goods they could trade without drawing on their probably dwindling resources. More importantly, however, it was part of an affirmation strategy. By joining the women's social peer group (one of the criminals was a brother, another a lover of one of the women ${ }^{47}$ ), they strengthened the notion of commonality with them. The second element of this affirmation strategy was to confirm existing antisemitic stereotypes. Not only did the men promise a life of comparative plenty, but they did deliver, thus making their claims of a future life in affluence credible.

A third element is active role-play on part of the men. This included an attempt to aggrandize and minimize their Jewishness at the same time and according to circumstance. For Freiberg and Rozenfeld, they invented fictional biographies. Freiberg became "the son of the owner of the largest factory in Lodz [sic!]. There are important streets, which belong entirely to them." ${ }^{48}$ And Rozenfeld was not only renamed Semyon Sergeevich Struvolev but made into a Soviet officer and air force pilot. ${ }^{49} \mathrm{He}$ "had bombarded Berlin several times, had parried an attack of six German war planes all alone and had destroyed three of them before being shot down." ${ }^{50}$ Crucially, however, Rozenfeld was made into a non-Jew and a Russian Orthodox Christian. ${ }^{51}$ This was part of Józef Serczuk's plan to establish himself as the lover of Yanka and Rozenfeld as the lover of Yula - to whom a non-Jewish partner would be more palatable..$^{52}$ The aim was not merely to establish sexual relations but to make the two women

\footnotetext{
46 Ibidem, 351.

47 Ibidem, 369.

48 Ibidem, 345.

49 Freiberg, “Sobibór”, 649.

50 Idem, To Survive, 345.

51 Ibidem, 351; Freiberg, "Sobibór”, 647.

52 Freiberg, To Survive, 351.
} 
believe that the men were in love with them in order "to make them want us to stay." 53 For a while, this make-belief worked. ${ }^{54}$ In his 1988 memoirs, Freiberg is philosophical about the situation: "The chance to be physically intimate with someone, even if she was ugly, was a rare opportunity, not to speak of sleeping in a bed and not on the floor. In any case, this was no time for hesitation. Our lives depended on the two lovers' success [...]." 55

It is difficult to acquire a sense of the women's perspective on this. In his 1988 memoirs, Freiberg repeatedly claims that Yanka did fall in love with Józef Serchuk. In the perhaps most memorable two examples, Freiberg's focus, however, is on something else - the acting skills of the men:

She [Yanka] was very much in love with Yozhik, and one day she said, "Now you say that you love me, and you treat me like a queen. But when the war is over, you will leave me. You will find a Jewish woman and get married to her...”. Yozhik pretended to be angry and left the room in a huff, and Yanka, looking worried, sent me to see what he was doing. Yozhik wet his cheeks with saliva, and I returned to Yanka and told her that Yozhik was crying. Yanka held her head in her hands. “Oh, God, what have I done?” she cried. "I shouldn't have said that to him. Go, bring him back." I went and came back. "He doesn't want to come," I said. Weeping, Yanka ran to Yozhik, kissed him and begged him to forgive her. ${ }^{56}$

The inherent danger in any changes of the emotional constellation is present just as is the need of the men to stabilise it. Occasionally, this made elaborate theatricals necessary:

Another time, she told Yozhik that she knew he didn't really love her, but only wanted to stay in her house until the end of the war. Yozhik was so insulted that he took a knife and began to sharpen it, shouting, "I have nothing to live for!” We jumped on him and held him down by force, and he struggled with us, trying to commit suicide by stabbing himself, shouting again and again, “I don't want to live!” Yanka, shaken by Yozhik's reaction, announced in a voice trembling with feeling, "If anything happens to Yozhik, I'll kill myself, too. I am to blame for everything." 57

\footnotetext{
53 Ibidem, 351.

54 Ibidem, 354.

55 Ibidem, 351.

56 Ibidem, 365.

57 Ibidem.
} 
However, when Yanka was due to give birth it was Józef Serczuk who acted as midwife. ${ }^{58}$ Even with all due caution, the impression is that Yanka felt emotionally close to Józef Serczuk. For her, at least, the relationship appears not to have been a rational one. As Freiberg told the story in 1988, Yula was different. She was a difficult and demanding woman, and she only believed that Rozenfeld was not Jewish for a limited period of time. Eventually, Rozenfeld and Yula fell out. At this point, the four men held an "emergency meeting," and they decided to replace the actor for the part of Yula's lover - Dawid Serczuk took over. Freiberg relates his scepticism:

I didn't think that Monyek [Dawid Serczuk] was suited to the role of Yula's lover. He was delicate and fastidious, and a perfectionist. Yula had more than once made fun of his refined language, saying that he wasn't speaking Polish and that he was "making words up." Sometimes Monyek would recite excerpts from books written by famous Polish authors, and Yula would interrupt him with profanities - she was blindly antagonistic to anything she wasn't familiar with. One evening, when Monyek explained that Jesus had been a Jew, she acted as if Monyek had thrust a dagger into her heart. She was so upset that she could have killed him. Monyek tried to calm her down and brought her simple evidence to prove what he had said, but she, who had absorbed anti-Semitism [sic!] from childhood, was offended to the depths of her soul, wept for a long while and shouted, "Aren't you ashamed to say that our beloved Jesus was a Jew?" ${ }^{59}$

In order to convince Yula, again, some carefully stage-managed acting was necessary:

It was difficult for me to imagine how there could ever be harmony between the two of them, but Monyek took the mission seriously. In the evening, when we were sitting together, and Yula and Semmen [Semyon Rozenfeld] started to taunt each other, Monyek interrupted them angrily and began hurling accusations at Semmen. "I've been heartsick at the way you've been treating Yula for a long time” said Monyek angrily. "I’ve loved Yula from the first moment I saw her!" Semmen answered that what went on between them was none of Monyek's affair, then Monyek attacked Semmen and tried to hit him, but we restrained him until he had calmed down. Yula watched this scene dumbfounded, then got up and sat down next to Monyek, and again sobbed and swore at Semmen. That night, Monyek slept in Yula's bed and Semmen joined me on the floor. ${ }^{60}$

\footnotetext{
58 Ibidem, 368.

59 Ibidem, 362-363.

60 Ibidem, 363.
} 
This change of assigned roles brought new challenges for the group, as the women focussed their attention on their two "lovers" and questioned the right of Rozenfeld and Freiberg to stay. ${ }^{61}$ The Serczuk brothers who threatened to leave and take their group elsewhere, however, quickly rebutted these attempts. ${ }^{62}$ More dangerous, perhaps, was the fact that Stashek, Bronek and Pan Folka had been caught and killed..$^{63}$ The immediate reaction of the four men was to hide in the forest. They only returned one week later. ${ }^{64}$

\section{Liberation}

In the spring of 1944, the war was not over but the growing insecurity and instability in the Chełm region foreshadowed its end. There was interethnic violence between Poles and Ukrainians, and the killing of Stashek, Bronek and Pan Folka was partly due to this. ${ }^{65}$ Various partisan groups of different denominations increased their activity, too, and the retreat of German forces meant a greater German presence of highly nervous soldiers along the main routes of transport. In addition, the warmer weather brought the local farmers out into their fields again, and all this made the peripheral house unsafe. Freiberg reported in 1945: "Earlier, when we went to get water, we had dressed like girls, with long dresses and caps on our heads, but that was not possible anymore." 66 Too many people were curious about the house and they came too close. The final months and weeks before the arrival of Soviet troops, the group led an itinerary life again, hiding in the forest, in fields and with farmers. The day the war ended for them, they spent with the farmer Karpiuk.

\section{Freiberg's two Narratives: Conclusions}

In their introduction to the 2014 edition of Freiberg's 1945 testimony, the editors note that much of his statement remained mysterious ${ }^{67} \mathrm{Had}$ they compared the text with his memoirs, some of what seemed unintelligible to them would probably have become clearer. And yet, profound questions remain. The most obvious difference is the fact that the sexual barter

\footnotetext{
61 Freiberg, “Sobibór”, 648.

62 Idem, To Survive, 365-366.

63 Ibidem, 375-377.

64 Ibidem, 375-376.

65 Ibidem, 375-377; Freiberg, "Sobibór”, 650.

66 Freiberg, “Sobibór”, 650.

${ }^{67}$ Ibidem, 618. The greatest mystery, of course, are the two women and the Serczuk brothers themselves. We know practically nothing about them, and Freiberg appears to be the only source on them. Further research is required.
} 
is not mentioned explicitly in Freiberg's 1945 deposition with the Central Jewish Historical Commission in Łódź. It is possible that Freiberg used code when he mentioned the promise of marriage, for example. Equally valid would be the assumption that he did not want to talk about matters concerning sexuality in front of a woman - in this case Bluma Wasser who recorded his statement. After all, in 1945, he was only seventeen. His age may very well have made him the ideal observer of what was going on. Clearly, Freiberg was able to understand everything, but he was no party to the sexual barter himself. Forty years later, writing his memoirs in Israel, a grown man in a very different social context, sexuality clearly no longer carried the same notions of shame and embarrassment.

Perhaps, the most striking variation in terms of content between the two narratives is a very different treatment accorded to two crimes. In his 1945 testimony, he had Bluma Wasser record the fate of the volksdeutsche lover:

One of the women had a lover, a Volksdeutscher. But she, faithful to her Jewish lover, did not want to receive him. He was surprised: "Janka, what is it with you, yesterday, you were quite different?” We realized that we would be discovered because of him. In the village, too, some knew about us. So we decided to kill him. One time, when he came to her, we left the chamber and went outside. When he came out again, we killed him, threw him into the canal and that was that. ${ }^{68}$

This account of premeditated murder is completely missing from the 1988 memoirs. Instead, a different crime is recorded - a robbery. The 1945 version reads like this:

We learned of a wedding, and that there was baking and cooking there the night before. We broke in, only showed our rifles and everyone put their hands up. We were led into the cellar and we were the lords of the manor. There were so many things that we harnessed horse and carriage and took everything, everything. We prepared a wedding for him [the groom] for which he only had underpants left. ${ }^{69}$

In the 1988 version of events, Freiberg introduces the story by noting his horror. Here, in addition to a comprehensive robbery, Bronek and Stashek rape the bride. ${ }^{70}$ The interesting question is not, whether the murder and the rape took place or not. We will never know. It

\footnotetext{
68 Ibidem, 648.

69 Ibidem, 649.

70 Freiberg, To Survive, 371-372.
} 
is much more fruitful to look at what both episodes, their inclusion and omission reveal about the two texts in question. In 1988, Freiberg went to some lengths to construct a moral difference between the four Jewish fugitives on the one hand, the women and their social milieu on the other. Immediately after relating the first meeting with the criminals at the house occupied by Yula and Yanka, Freiberg writes that the four men "had never dreamed that their home was a hideout for burglars und murderers.” He continues:

No doubt, if we had had somewhere else to go, if it had been summer and we could have slept outside, we would have left immediately and never gone back. But it was still bitterly cold outside, and we had nowhere else to go. With no alternative, we had to endanger ourselves and remain with them. ${ }^{71}$

In Freiberg's 1945 testimony, this moral difference and the fundamental ambivalence are lacking as the very straightforward story of the murder underlines. Indeed, there is a level of reflection in the 1988 autobiography, which is missing in the earlier text:

Sometimes I found justification for the robberies we carried out - why should only the Jews suffer? Let these non-Jews get a taste of our suffering. I saw our deeds as a kind of retribution for the "Polacks" who had helped to destroy the Jews, but I couldn't stomach the cruelty of Bronek and his friend, Stashek, and the suffering of the girl. (...) For a long while, I kept hearing the screams and sobs of the bride and reliving the scene of Bronek with his pants pulled down. ${ }^{72}$

Interestingly, Freiberg's attitude towards non-Jewish Poles hardened considerably between 1945 and 1988. In 1945, he showed a higher degree of understanding for the situation of the local non-Jewish population. Probably, Karpiuk begged Serczuk to leave his farm again for fear of his entire family being killed by the Germans. Freiberg's 1945 reaction was to say, "he was right." ${ }^{\prime 3}$ Statements like this are absent from his 1988 book. Instead, the focus is very much on the hopelessness of the situation of Jews seeking to hide among the local population:

Now I understood the people who had come to Sobibór and told of how they had run away from the ghetto and tried to live in the forests, but in the end, had returned to the ghetto

\footnotetext{
71 Ibidem, 354.

72 Ibidem, 372.

73 Freiberg, “Sobibór”, 646.
} 
and wound up in Sobibór, because their experience had made it clear to them that Jews were not welcome anywhere - they were persecuted not only by the Germans but also by the Poles and the Ukrainians. And in fact, during the few days since we had run away from Sobibór, it had become clear to us, too, that we had no place in this world. ${ }^{74}$

Yet, the greater level of detail, the many more episodes Freiberg can relate in his 1988 book blur the picture again. He therefore writes of a number of incidents of having received help from the local population alongside the cases of having been attacked or rejected. ${ }^{75}$ What emerges is a deeply ambivalent and highly individual story, which chimes in well with what historical research has shown in recent years.

Both texts are of the greatest value as sources. The level of reflection and detail in the 1988 memoirs is in stark contrast to the rawness and abruptness of the 1945 statement. When read together, things begin to make more sense. Forty years after the events, Freiberg no longer takes things for granted - what Bluma Wasser knew in 1945, he did not have to spell out. The interested reader in 1988, however, needs more explanations. For example, Natalia Aleksiun has written about surrogate families in hiding, ${ }^{76}$ and it is no coincidence that in 1945, Freiberg calls Józef Serczuk "our father" ${ }^{77}$ When reading the longer memoirs, one begins to understand why Freiberg would do that.

As with most autobiographical writings, Freiberg's 1988 memoirs not only explain his life to the reader but in many ways to the author as well. It is this attempt to make sense of what happened, which is so valuable as it appears to trigger memories which otherwise might not have been made public or not surfaced at all. The very rare story of male sexual barter in rational relationships contained in his memoirs is a poignant and powerful reminder of the value of late testimonies.

\footnotetext{
74 Idem, To Survive, 310.

75 Ibidem, 311-316.

76 Natalia Aleksiun, "Uneasy Bonds: On Jews in Hiding and the Making of Surrogate Families," in: Jewish and Romani Families in the Holocaust and Its Aftermath, eds. Eliyana R. Adler, Kateřina Čapková (Rutgers, NJ: Rutgers University Press, 2020), 85-99.

77 Freiberg, “Sobibór”, 643.
} 


\section{Bibliography}

Aleksiun, Natalia. “Uneasy Bonds: On Jews in Hiding and the Making of Surrogate Families.” In: Jewish and Romani Families in the Holocaust and Its Aftermath, eds. Eliyana R. Adler, Kateřina Čapková, 85-99. Rutgers, NJ: Rutgers University Press, 2020.

Arad, Yitzhak. Belzec, Sobibor, Treblinka: The Operation Reinhard Death Camps. BloomingtonIndianapolis: Indiana University Press, 1987.

Bem, Marek. Sobibor Extermination Camp 1942-1943, transl. Tomasz Karpiński, Natalia Sarzyńska-Wójtowicz. Amsterdam: Stichting Sobibor, 2015.

Blatt, Thomas Toivi. Sobibór - der vergessene Aufstand. Hamburg-Münster, UNRAST Verlag, 2004.

Browning, Christopher R. Remembering Survival: Inside a Nazi Slave-Labor Camp. New York: Norton, 2010.

Freiberg, Berek. “Sobibór.” In: Nach dem Untergang. Die ersten Zeugnisse der Shoah in Polen 19441947. Berichte der Zentralen Jüdischen Historischen Kommission, eds. Frank Beer, Wolfgang Benz, Barbara Distel, 617-652. Dachau-Berlin: Verlag Dachauer Hefte-Metropol, 2014.

Freiberg, Dov. To Survive Sobibor. Jerusalem-New York: Gefen, 2007.

Hájková, Anna. "Sexual Barter in Times of Genocide: Negotiating the Sexual Economy of the Theresienstadt Ghetto.” Signs 38 (2013), 3: 503-533.

Hájková, Anna. “Strukturen weiblichen Verhaltens in Theresienstadt.” In: Genozid und Geschlecht: Jüdische Frauen im nationalsozialistischen Lagersystem, ed. Gisela Bock, 202-219. Frankfurt a. M.: Campus, 2005.

Joseph Serchuk. Wikipedia. Access 13.08.2020. https://en.wikipedia.org/wiki/Joseph_Serchuk.

List of survivors of Sobibor. Wikipedia. Access 13.08.2020. https://en.wikipedia.org/wiki/ List_of_survivors_of_Sobibor.

Semjon Rosenfeld. Wikipedia. Access 30.08.2020. https://de.wikipedia.org/wiki/Semjon_Rosenfeld. Waxman, Zoë. Women in the Holocaust: A Feminist History. Oxford: Oxford University Press, 2017.

\section{Seks, miłość i kłamstwa we wspomnieniach Dova Freiberga To Survive Sobibor}

Streszczenie

Po ucieczce z niemieckiego obozu śmierci w Sobiborze 14 października 1943 r. Dov Freiberg i Semyon Rozenfeld ukrywali się w okolicach Chełma do przybycia Armii Czerwonej w lipcu 1944 r. W 1945 r. Freiberg złożył zeznanie przed Centralną Żydowską Komisją Historyczną, a w 1988 r. opublikował obszerne wspomnienia zatytułowane To Survive Sobibor (Przetrwać Sobibór). W obu 
tekstach opisał okres ukrywania się wraz z Rozenfeldem oraz braćmi Dawidem i Józefem Serczukami. Żydowscy uciekinierzy znaleźli schronienie u dwóch kobiet, z którymi zbudowali tymczasowe związki. W obu tekstach Freiberg wspomina o seksualnych i emocjonalnych relacjach z kobietami, które mężczyźni postrzegali jako narzędzie służące zabezpieczeniu ich trudnej sytuacji w ukryciu. Porównując oba źródła, autor artykułu wskazuje, jak ważne w badaniach nad Zagładą są tzw. późne relacje.

\section{Słowa kluczowe}

Sobibór, Dov Freiberg, Semyon Rozenfeld, Dawid Serczuk, Józef Serczuk, seksualność, Holocaust, ukrywanie się

PROSIMY O CYTOWANIE TEGO ARTYKUŁU JAKO:

Raphael Utz, „Making Love and Make-Belief: Male Sexual Barter in Dov Freiberg’s To Survive Sobibor, Autobiografia: Literatura. Kultura. Media 1 (2020), 14: 75-92. DOI: 10.18276/au.2020.1.14-05 